\title{
The Effect of Training on Employee Retention
}

\author{
Mengjun Chen \\ Department of Economics and International Business \\ Fujian Jiangxia University \\ Fuzhou, China \\ 10269357@qq.com
}

\begin{abstract}
The purpose of this report is to examine the relationship between training and employee retention. Training is beneficial to the organization performance and specifically it is a core organizational strategy influencing the employee retention and human capital growth. However, there is not enough investment on training activities because some employers view training as an expensive risk. Based on human capital theory and psychological contract theory, this report analyzes why training might influence retention.
\end{abstract}

Keywords-training; employee retention; psychological contract

\section{INTRODUCTION}

Nowadays many organizations have realized that they must focus on employee retention as one of the most critical business objectives in order to keep the organization competitive and profitable (Arthur, 2001). There are three main reasons why employees leave the organization: retirement, dismissal or voluntary resignation. Retirement and dismissal are decisions made by the organizational management while voluntary turnover is a personal decision of the employee (Winterton, 2004). This research report focuses on the voluntary separation rather than retirement and dismissal from the organization. Although the departure of an employee with poor performance is encouraged by the organization, a high turnover of talented employees will result in a loss to the organization. It is costly to replace the intelligent capital via recruiting and training new ones. More insidiously, employees' departure might badly influence other colleagues' morale and the organization performance.

There are external and internal drivers in relation to employee retention. For example, labor market opportunity and organizational culture are the external factors that influence turnover. From an employee's perspective, they aspire for career development, which is a primary motivational factor to remain in the organization. External factors are beyond employer's control but the employer can take some measures to improve employee retention in conjunction with the internal factors. Effective training provided is one of the ways to keep talented employees to stay longer in an organization. Training, if utilized effectively, may increase the job satisfaction and organizational commitment and employees tend to stay longer in the organization. Involving knowledge, skill and ability, training is valuable both to an organization and individual employees.

However, many organizations are not willing to provide employee with training because training could be an expensive risk. Equipped with better skills as a result of training, some employees may leave the organization and seek for a better job. If training is essential to keep the organization competitive and increase profits, why are some companies choosing not to support lifelong learning?

\section{LITERATURE REVIEW}

\section{A. Human Capital Theoretical Framework}

Training and development have often been hailed as a core organization strategy influencing both employee retention and human capital growth. Economists have different interpretations of the term "human capital" in different ways. Most of them agree that human capital comprises of skills, ability, experience and knowledge. Human capital refers to the intangible resource of ability, effort, and time that workers bring to invest in their work. As shown in figure 1, Gratton and Ghoshal (2003) define human capital as being made up of intellectual capital, social capital and emotional capital. According to the resource-based view (RBV) of the organization, competitive advantage depends on the valuable, rare and hard-to-imitate resources. Human capital is such an invaluable resource that it is one of the most important determinants whether the organization can be successful in today's fierce competition. Thus, in order to create valuable virtues, many employers have shifted from the financial capital to the intellectual capital focus.

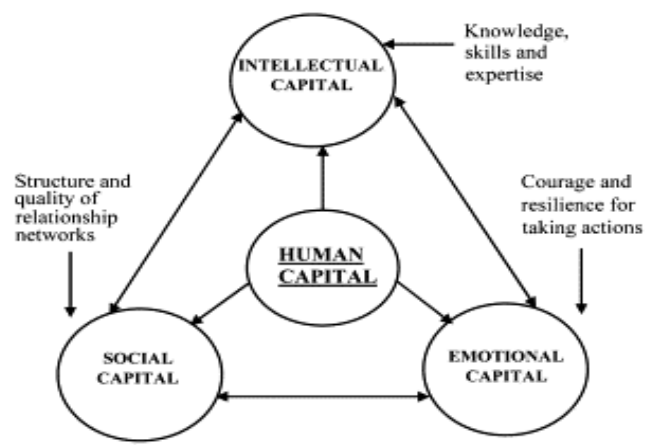

FIGURE I. FIGURE 1: HUMAN CAPITAL CONSISTS OF THE INTELLECTUAL, SOCIAL AND EMOTIONAL CAPITAL OF INDIVIDUALS AND ORGANIZATIONS

\section{(SOURCE: GRAFTON AND GHOSHAL, 2003, P.2)}

1) Employee retention:As human capital plays an important role in organization's success, more and more employers are aware of the fact that it is of great importance to keep the 
talented employee in the organization. Employee retention is a serious and critical problem for all types of organizations. As per the term "employee retention", it first appeared on the business scene in the 1970s and early 80s (Mckeown, 2002). Successful employee retention helps preserve the knowledge within an organization. If the employee leaves the organization, a knowledge gap is generated. In addition, the organization will be faced with a significant loss such as reduction in organizational performance if the turnover of talented employees is high. The reason for this is that it is costly to replace the intelligent capital via recruiting and training. In order to preserve the human capital, it is necessary for the organization to analyze why the employees leave the organization and come up with employee retention solutions.

2) Training:The value of the organizational stock of human capital can be added to by training. Investments in human capital especially through personnel training are considered increasingly important for the success of the organizations. The benefits of training have been well-documented. Training improves employee productivity, for example, training decreases wastages, accidents and absenteeism. Rather than focusing empowerment, employers need to train the work force effectively to improve employee job performance. The most specific benefits of training and development is that it is best seen as an incentive to enhance employee retention, especially to keep those who have ambition to seek career advancement in their work. Nowadays most of the employees are eager for the chance to learn new things so that they can take new responsibilities. Training can motivate the employee and build organizational commitment and loyalty as training make them realize the organization is helping them to achieve their career goal.

\section{B. Psychological Contracts Theoretical Framework}

A review of literature indicates a number of plausible psychological factors in explaining why effective training helps ensure better employment. One of the most important theories is psychological contract theory.

1) Psychological contract: A Social Exchange Perspective: In understanding the dynamics of psychological contract in employment, it may help elaborate upon the social exchange theory on which psychological contract theory is based. The social exchange theory is a base to understand employment relationship as the social exchange theory states that a party offers benefit to another party leading to social obligations felt by another party; another party often reciprocate to discharge this obligation. According to Rousseau (1995), psychological contract refers to an individual's belief regarding the reciprocal obligations between employees and their employers. The psychological contract presents an unwritten set of assumptions and expectations upon which the relationship of the employer and employee are based. Robinson (1996) notes that the psychological contract refers to employees' perceptions of what they owe to their employers and what they are owed from the employers. However, based on reciprocal exchange, psychological contract must be distinguished from the expectations because it entails a belief in what the employer is obliged to provide (Robinson \& Rousseau, 1994).

2) Organizational commitment:Organizational commitment is described as a predictor of turnover because it is important to employee retention. It is viewed as a psychological state regarding the employee's relationship and indicates whether the employee will want to continue staying in the organization as a member. As affective commitment relates to retention consistently, it is the most widely used. The more feeling of the access to training, the higher affective commitment the employee has. A highly committed employee shows loyalty because they would like to stay in the organization longer than others who are less committed and work harder to achieve the organizational goals.

Coyle-Shapiro and Kessler (2002) use the psychological contract to examine the reciprocity from the employee and employer perspective by adopting the social exchange theory. Eisenberger and Aselage (2003) describe if the employee receives the support from the employers, such as training, they will trust the employer and will be more obliged to reciprocate. Bruvold and Lee (2003) also explore in their research that perceived investment in employee development is positively related to the affective commitment and the employee's intention to stay in the organization. In the psychological contract, it has been well documented that employees invariably hold expectations that organizations may provide them with training opportunities beneficial to individual advancement and development. When an organization offers desirable training to employees, it may be interpreted as employer expressing employee concern and care. Training may be viewed as an advancement opportunity, the employees might perceive the organization values them as individuals and fosters their self-worth. The perception of a caring and trustworthy organization will ultimately evoke a sense of obligation that takes the form of enhanced commitment and reduced turnover. Meanwhile, employee would appreciate the skills they have required via training provided by the employer and be aware the training expenses the organization has spent on them. They therefore might develop a sense of obligation for the employer and become more committed to the organization and be ultimately less likely to quit.

3) Psychological contract violation:Conversely, a number of studies have found that when the psychological contract is violated, employees' trust and benevolence to their employers, job satisfaction, intention to remain the organization and perceived obligation to the organization are decreased. The greater the extent of failure of the employers fulfilling their obligations to the employees, the more the employees would lower their perceived obligations to the organization (Coyle-Shapiro \& Kessler, 2002).

Psychological contract violation refers to one's perception that another has failed to fulfill the promised obligation (Rousseau, 1995). A perceived psychological contract violation such as an unmet expectation occurs when employees perceive they have not been reciprocated as promised after 
they have made the contribution to the organization. In addition the contract violation also occurs when employees find they have not got anything that should have been forthcoming. It is important to note that the process and situation by which the employer perceives the contract violation may be perceived and illustrated in a different way. Robinson (1996) indicates psychological contract breach is a subjective experience. It is based not only actual breach but on an employees' perception of the extent to which the employer has failed to fulfill the promised obligation. Trust therefore plays a significant role in employees' perception of a breach.

There are a number of common types of psychological contract violation (Rousseau, 1995). Robinson and Rousseau (1994) describe the different types of violation in psychological contract, which include training/development, compensation, promotion and the nature of job. As shown in table 1, among all the different types of violation, training and development violation is the most frequent.

TABLE I . TYPES OF VIOLATIONS

\begin{tabular}{|l|l|c|l|}
\hline \multicolumn{1}{|c|}{$\begin{array}{c}\text { Violation } \\
\text { Type }\end{array}$} & \multicolumn{1}{|c|}{ Definition } & $\begin{array}{c}\text { Frequen } \\
\text { cy }\end{array}$ & \multicolumn{1}{c|}{ Examples } \\
\hline $\begin{array}{l}\text { Training \& } \\
\text { development }\end{array}$ & $\begin{array}{l}\text { Absence of } \\
\text { training or } \\
\text { training not as } \\
\text { promised }\end{array}$ & 65 & $\begin{array}{l}\text { "Sales training } \\
\text { was promised as } \\
\text { an integral part of } \\
\text { marketing } \\
\text { training. It never } \\
\text { materialized." }\end{array}$ \\
\hline $\begin{array}{l}\text { Compensatio } \\
\mathrm{n}\end{array}$ & $\begin{array}{l}\text { Discrepancies } \\
\text { between } \\
\text { promised and } \\
\text { realized pay, } \\
\text { benefit, bonuses }\end{array}$ & 61 & $\begin{array}{l}\text { "Specific } \\
\text { compensation } \\
\text { benefits were } \\
\text { promised and } \\
\text { either were not } \\
\text { given to me, or I } \\
\text { had to fight for } \\
\text { them." }\end{array}$ \\
& $\begin{array}{l}\text { and } \\
\text { and }\end{array}$ & & \\
\hline
\end{tabular}

(extracted source: Robinson and Rousseau, 1994, p.273)

From the employees' perspective, employer breach of the psychological contract may be perceived in several ways. A review of the literature indicates that there is little research to illustrate how the training type of violation influences the employee's intention to leave the organization. Therefore, I would like to further explore in more details the different circumstances under which the training/development type of violation in psychological contract results in employee turnover:

- The organization does not think of providing training at all.

Apart from some employees who do not want to receive training, most of the employees anticipate training opportunity to be available as it is beneficial for their individual growth and development. However, some employers view training as a high investment and risk, so they do not want to offer training to their employees. In some small organizations, the organizational size, time and money are the constraints in providing training. Without training, the employees may feel boring and can't forecast any career development and prospect, so they want to quit the job.

- The employee does not provide employee training as promised.

In order to attract new employees to join, employers promised to provide training at the very beginning. But after staying for a period, employees find the organization does not provide the training as it originally promised, even the employers sort out kinds of excuses faced with employees' question that when the training will be provided. The employee may feel they have been cheated.

- The provided training is not tied up with the present job and the employee cannot develop the skill they want to achieve.

Employees want to improve their job skill after working for the organization for a while, but if the employer provides training that is not related to the job skills, this could be a problem. For example, when the employee first joins the organization, it is good to provide orientation training. But some time later, if the employer still provides training, which only remain at the orientation level, the employees will not be satisfied. After the training, employees perhaps realize they haven't made any job skill improvement therefore they regard the training as of little or no value.

- After training, the employee has no opportunity to utilize their new skill into practice.

Employers are not sure about the new trainee's performance after training given and hence they do not provide the opportunity for the new trainee to try the new job. Instead, employers still let the job be conducted by employees who already have experience. Employees also maybe regard training as no value if there is no opportunity for them to apply the new skills into practice.

- After training, the employee cannot get the according compensation, such as a higher salary, when the productivity increased.

This situation is combined with compensation. Normally once training is evaluated to be effective and it has achieved the goal that the employee job performance has been improved; employee takes it for granted that he is becoming a higher-level employee who will make more contribution to the organization. Accordingly, they will anticipate that the employer will offer a better salary. However, the employer feels that it is difficult to afford a higher compensation. The employee may begin to look for another better job opportunity, with an organization that can provide better remuneration.

On the other hand, from the employer's perspective, the employees may actually breach the psychological contract. For example, the employee may be lured by another organization's higher monetary rewards, even though the employer has provided employees with satisfactory training. If the employee cannot resist the temptation and there is a lack of organizational commitment, they may leave the organization after they have received training. 
After interpreting the psychological contract violation model, it is fair to assume that training should be implemented in the right way in order to keep the experienced employee. Firstly, training objectives must be carefully designed and the action plans must be developed. Secondly, training must be tied closely to the right training methods. Thirdly, training provided should be relevant to both organization and individual's needs. This can be achieved by letting employee choose what skill and knowledge they want to improve.

\section{CONCLUSIONS AND FUTURE DIRECTIONS}

The afore-mentioned discussion can be summarized into the following theoretical framework (see figure 2) in this research report.

In the today's knowledge economy era of today, human capital is one of the most important determinants of the organization success, as it is an invaluable resource that can be equipped with knowledge and skill to create valuable virtues. Training and employee retention are two important parts in human resource management area.

Psychological contract links training with retention and explains why training influences retention based on social exchange theory. Training develops the employee commitment making them feel the obligation to reciprocate the employers. Thus they stay longer in the organization after training provided. On the other hand, training makes employees feel the organizational supports and trust the employer. Hence, training is positively related to trust in management and reduces employee turnover. Conversely, when the psychology contract is breached, the employee will leave the organization. After the literature review, I have explored the different circumstances of training in psychological contract violation.

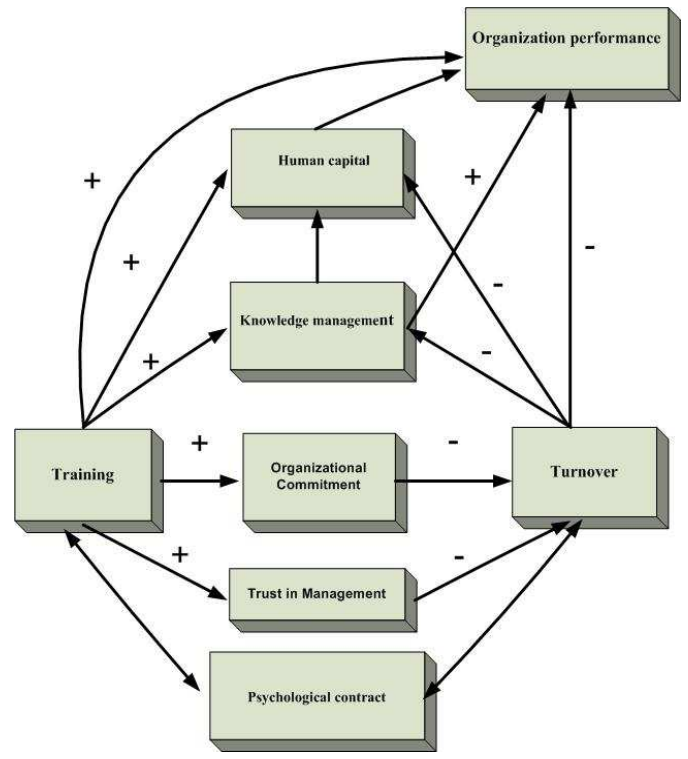

\section{FIGURE II. THE INTERRELATIONSHIP BETWEEN TRAINING AND EMPLOYEE RETENTION}

It follows from the foregoing discussion and analysis that three interesting questions emerge, which may deserve future research attention.
Firstly, while the most of the research have largely focused on the relationship between training and retention, few of them has been devoted to evaluating the costs of training versus the benefits it may render. Since training can often be an expensive undertaking that may pose additional burden on the organization, it may help to shift research focus towards measuring the efficacy of training in dollar terms. More specifically, research attention should focus on how much dollar value can be generated if specific training is invested in, and whether the results can be applied across a range of industries.

Secondly, it may worthwhile conducting research on the relationship between training effectiveness and the individual profiles of trainees. Studies on Big-five personality which refers extroversion vs. introversion, conscientiousness, agreeableness, neuroticism and openness to experience, may offer some insights into the relationship between training and individual profiles of trainees. Future research can move beyond personality and towards other individual characteristics such as intelligence, gender and ethnicity.

Lastly, it should be noted that the primary concern of an organization is, more often than not, performance rather than turnover. In some cases, turnover may be positive in the sense that employees with unsatisfactory performance are encouraged to leave. As such, the variables in the research may need to be re-examined in terms of the extent to which training can engender employee performance and commitment.

\section{REFERENCES}

[1] Arthur, D. (2001). The employee recruitment and retention handbook New York: Amacom.

[2] Chang, C.L. (2010) The study of the turnover of MIS professionals-The gap between Taiwanese and US societies. International journal of information management, 30(4), 301-314

[3] Coyly-Shapiro, J.A.M., Kessler, I. (2002). Exploring reciprocity through the lens of the psychological contract: Employee and employer perspectives. European journal of work and organizational psychology, 11(1), 69-86.

[4] Eisenberger, R. \& Aselage, J. (2003). Perceived organizational support and psychological contracts: a theoretical integration. Journal of organizational behavior, 24(5), 491-509.

[5] Guest, D. E. (1998). Is the psychological contract worth taking seriously? Journal of organizational behavior, 19(7), 649-664.

[6] Gartton, L. \& Ghoshal, S. (2003). Managing personal human capital: New ethos for the "volunteer" employee. European management journal, 21(1), 1-10.

[7] Mckeown, J. L. (2002). Retaining top employees. New York, USA: McGraw-Hill.

[8] Morrison, E. W. \& Robinson, S. L. (1997). When employees feel betrayed : A model of how psychological contract violation develops. Academy of management review, 22(1), 226-256.

[9] Nouri, H. \& Parker, R.J. (2013). Career growth opportunities and employee turnover intentions in public accounting firms. The British Accounting Review. 45(2), 138-148

[10] Robinson, S. L. (1996). Trust and breach of the psychological contract. Administrative science quarterly, 41(4), 574-599.

[11] Rousseau, D.M. (1995). Psychological contracts in organizations: Understanding written and unwritten agreements. Thousand Oaks, CA, USA: Sage.

[12] Rousseau, D.M. (2004). Psychological contracts in the workplace: Understanding the ties that motivate. Academy of Management Excutive. 18(1), 120-127.

[13] Winterton, J. (2004). A conceptual model of labor turnover and retention. Human resource development international, 7(3), 371-390. 